\title{
Insulin-like growth factors decrease oxygen-regulated erythropoietin production by human hepatoma cells (Hep G2)
}

\author{
HOLGER SCHOLZ, WOLFGANG BAIER, PETER RATCLIFFE, KAI ECKARDT, \\ JÜRGEN ZAPF, ARMIN KURTZ, AND CHRISTIAN BAUER \\ Physiologisches Institut der Universität Zürich and Stoffwechsellabor, Universitätsspital Zürich, \\ CH-8057 Zurich, Switzerland; John Radcliffe Hospital, Oxford 0X3 9DU, United Kingdom; \\ and Institut für Physiologie I, Universität Regensburg, W-8400 Regensburg, Germany
}

\begin{abstract}
Scholz, Holger, Wolfgang Baier, Peter Ratcliffe, Kai Eckardt, Jürgen Zapf, Armin Kurtz, and Christian Bauer. Insulin-like growth factors decrease oxygen-regulated erythropoietin production by human hepatoma cells (Hep G2). Am. J. Physiol. 263 (Cell Physiol. 32): C474-C479, 1992.-We examined the effects of insulin-like growth factors (IGFs) and insulin on erythropoietin (EPO) production by human hepatoma cells (Hep G2). Compared with normoxia $\left(20 \% \mathrm{O}_{2}\right)$, EPO production by Hep G2 cells during a 72-h incubation was stimulated fivefold by exposure to low oxygen tension $\left(1 \% \mathrm{O}_{2}\right)$ and nearly threefold by exposure to cobalt chloride $(100 \mu \mathrm{M})$. IGF-I caused a concentration-dependent attenuation of EPO formation under normoxic conditions and inhibited (maximally 50\%) EPO production stimulated by either low oxygen tension or cobalt [half-maximal effect $\left(\mathrm{ED}_{50}\right) \approx 5 \mathrm{nM}$ ]. The increase of EPO mRNA levels in response to hypoxia was significantly reduced by IGF-I. Similarly to IGF-I, IGF-II $\left(\mathrm{ED}_{50} \approx 8 \mathrm{nM}\right)$ and insulin $\left(\mathrm{ED}_{50} \approx 80 \mathrm{nM}\right)$ also inhibited EPO formation in Hep G2 cells. IGF-I (100 pM-100 nM) stimulated the incorporation of radiolabeled alanine as a measure for total protein synthesis, ${ }^{3} \mathrm{H}$-labeled thymidine incorporation into DNA, and glycogen synthesis at 20 and $1 \% \mathrm{O}_{2}$ in a concentration-dependent fashion. IGF-I exhibited a high affinity for the IGF-I receptor (apparent $K_{\mathrm{d}} \approx 3 \mathrm{nM}$ ). Unlabeled insulin was $>100$-fold less potent than IGF-I in competing for ${ }^{125}$ I-IGF-I binding (apparent $K_{\mathrm{d}} \approx 360 \mathrm{nM}$ ). Conversely, insulin bound to the insulin receptor with high affinity (apparent $K_{\mathrm{d}} \approx 0.3 \mathrm{nM}$ ), whereas IGF-I was $<1 \%$ as potent in competing for ${ }^{125}$ I-insulin binding. In summary, IGFs and insulin exert a negative control function on oxygen-regulated EPO production in Hep G2 cells. The inhibitory effect of IGFs and insulin on EPO formation appears to be mediated via the IGF-I receptor.
\end{abstract}

hypoxia; cobalt; radioimmunoassay

ERYTHROPOIESIS is controlled by the glycoprotein hormone erythropoietin (EPO), which is predominantly produced in the kidneys and to a minor extent in the liver $(3,6)$. Recent studies suggest that insulin-like growth factor (IGF) I, the peripheral mediator of growth hormone effects $(5,28)$, may be involved in the regulation of red cell formation $(16,21)$. Thus IGF-I stimulates the proliferation of late erythroid precursors in vitro $(1,9,21)$, and administration of IGF-I to neonatal rats increases erythroid colony (CFUe) formation in the bone marrow (16). Furthermore, continuous infusion of IGF-I in hypophysectomized rats activates erythropoiesis proportionally to the body growth (11). Part of the erythropoietic activity of IGF-I may be mediated by EPO because serum EPO levels, which are subnormal in hypophysectomized animals, increased markedly to even above normal values during IGF-I administration (11). Because serum EPO levels closely correlate with the rates of de novo EPO synthesis in the organism (23), it was concluded that EPO production in hypophysec- tomized animals is stimulated by IGF-I. The mechanism, however, by which IGF-I increased EPO formation rates in hypophysectomized animals is unknown. In particular, those in vivo studies did not clarify whether IGF-I exerted direct effects on EPO-producing cells.

Studies on the cellular regulation of EPO formation are hampered by the fact that the EPO-producing cells from neither the liver nor the kidneys could yet be isolated and studied under controlled in vitro conditions. Recently, however, two human hepatoma cell lines (Hep G2 and Hep 3B) were found to produce EPO in an oxygen- and cobalt-regulated fashion as is characteristic of the in vivo situation $(4,15,24)$. Hence Hep G2 and Hep 3B cells are considered as suitable models for studies on the cellular mechanisms of EPO production.

In the present study we have used Hep G2 cultures to examine whether IGF-I has a direct regulatory effect on EPO-producing cells. We found that IGF-I, IGF-II, and insulin decreased basal $\left(20 \% \mathrm{O}_{2}\right)$ EPO formation in Hep G2 cells. Moreover, IGF-I, IGF-II, and, at 10-fold higher concentrations, also insulin inhibited hypoxia- and cobalt-activated EPO formation in Hep G2 cells in a dosedependent fashion. In competitive binding studies, both IGF-I and insulin cross-reacted with each other's receptors with affinities ranging $>100$-fold lower than for their own specific binding sites. Taken together, our findings suggest that both IGFs and insulin modulate EPO production through interacting with the IGF-I receptor.

\section{MATERIALS AND METHODS}

Materials. $\alpha$-Minimal essential medium ( $\alpha$-MEM) was obtained from Amimed (Basel, Switzerland). Fetal bovine serum was from GIBCO (Basel, Switzerland). Insulin was purchased from Sigma. IGF-I and IGF-II were gifts from Dr. K. Märki, Ciba-Geigy (Basel, Switzerland). ${ }^{125}$ I-labeled IGF-I and ${ }^{125} \mathrm{I}$ IGF-II were iodinated to specific activities of $40-80 \mu \mathrm{Ci} / \mu \mathrm{g}$, using the chloramine-T method as described by Zapf et al. (29). ${ }^{125} \mathrm{I}$-insulin, $\mathrm{D}-\left[{ }^{3} \mathrm{H}\right]$ glucose, $\left[{ }^{3} \mathrm{H}\right]$ alanine, and $\left[{ }^{3} \mathrm{H}\right]$ thymidine were obtained from Amersham.

Cell culture. Hep G2 cells were obtained from the American Type Culture Collection (Rockville, MD). They were kept in $\alpha$-MEM supplemented with $10 \%$ (vol/vol) fetal bovine serum in $25-\mathrm{cm}^{2}$ flasks, and they were routinely split twice a week (1:20 and 2 days later 1:10). Under these conditions the cells only reached subconfluency and did not form cell clusters. For the experiments, the cells were usually grown in 24 -well plates (surface area $2 \mathrm{~cm}^{2} /$ well) with $200 \mu$ l of culture medium. Cells were seeded at a density of $\sim 5 \times 10^{4}$ cells $/ \mathrm{cm}^{2}$. Seeding of cell clumps was avoided by brief and vigorous shaking of the trypsinized cell suspensions. At $24 \mathrm{~h}$ after onset of culture, the medium was replaced and the experiments were started usually for the next $72 \mathrm{~h}$. Each experiment was performed in quadruplicate wells. 
Cellular prolein concentralion. Cellular protein was taken as a measure for cellular mass. It was confirmed that the mean cellular protein content was the same under the different experimental conditions. To this end, the cells were incubated for 24 , 48 , and $72 \mathrm{~h}$ according to the experimental protocols. Thereafter they were trypsinized with $0.1 \%$ trypsin (Amimed), and aliquots of the cell suspensions were counted in a Neubauer chamber. Mean protein content of Hep G2 cells was $\sim 320 \mu \mathrm{g}$ protein $/ 10^{6}$ cells. For protein determination, the culture medium was removed and the cell layers were washed twice with $300 \mu$ l of phosphate-buffered saline (PBS). Then $500 \mu \mathrm{l}$ PBS supplemented with $0.1 \%$ Triton $\mathrm{X}-100$ was added, and the multiwell plates were shaken at room temperature for $30 \mathrm{~min}$. Thereafter the samples were centrifuged for $20 \mathrm{~min}$ at $4,000 \mathrm{~g}$ in a Sorvall RT 6000 centrifuge that was cooled to $4^{\circ} \mathrm{C}$. Protein content in the cell lysates was determined with a commercially available protein assay (Bio-Rad) using bovine serum albumin as a standard.

Determination of glycogen synthesis. Glycogen synthesis was determined by measuring $\mathrm{D}-\left[{ }^{3} \mathrm{H}\right]$ glucose incorporation into glycogen as described by Widmer et al. (26). At $24 \mathrm{~h}$ after seeding at a density of $5 \times 10^{4}$ cells $/ \mathrm{cm}^{2}$, Hep G2 cells were exposed to 20 and $1 \% \mathrm{O}_{2}$, respectively, in culture medium containing $7 \mathrm{mM}$ glucose and various concentrations of IGFs or insulin. After 24 $\mathrm{h}$, the culture medium was replaced and $0.5 \mu \mathrm{Ci}$ of $\mathrm{D}-\left[{ }^{3} \mathrm{H}\right]$ glucose was added to each well. After a 3 -h incubation period at $37^{\circ} \mathrm{C}$, the medium was removed and $200 \mu \mathrm{l}$ of $20 \% \mathrm{KOH}$ containing 1 $\mathrm{mg}$ of glycogen was added. The cells were kept at $60^{\circ} \mathrm{C}$ for 40 $\mathrm{min}$, and the cell lysates were transferred to tubes and incubated at $60^{\circ} \mathrm{C}$ for $1 \mathrm{~h}$. The tubes were cooled in ice water, and $1 \mathrm{ml}$ of cold absolute ethanol $\left(-20^{\circ} \mathrm{C}\right)$ was added. Glycogen was purified by centrifugation and two washes with $1 \mathrm{ml}$ of ethanol to which $20 \mu \mathrm{l}$ of $5 \% \mathrm{LiBr}$ and $20 \mu \mathrm{l}$ of $1 \mathrm{~N} \mathrm{KOH}$ had been added (30). The final precipitate was dissolved in $0.2 \mathrm{ml}$ of $0.2 \mathrm{~N} \mathrm{HCl}$ and counted in $5 \mathrm{ml}$ of $\mathrm{OptiPhase} \mathrm{MP}(\mathrm{LKB})$ in a liquid scintillation counter.

Determination of DNA synthesis. Cells were kept in $\alpha$-MEM containing unlabeled thymidine $(10 \mathrm{mg} / \mathrm{l})$ and various concentrations of IGFs and insulin. After $24 \mathrm{~h}$, new medium containing $1 \mu \mathrm{Ci}$ of $\left[{ }^{3} \mathrm{H}\right]$ thymidine was added to each well. Incubation was continued for $3 \mathrm{~h}$. Thereafter the cells were rinsed with ice-cold PBS, covered with $0.5 \mathrm{ml}$ of ice-cold $10 \%$ trichloroacetic acid (TCA), and kept at $4^{\circ} \mathrm{C}$ for $50 \mathrm{~min}$ to extract TCA-soluble material (22). After the cells were washed three times with cold $10 \%$ TCA, they were dried in an air stream and digested in 0.2 $\mathrm{ml}$ of $1 \mathrm{~N} \mathrm{KOH}$. After neutralization with $1 \mathrm{~N} \mathrm{HCl}$, radioactivity was counted in $5 \mathrm{ml}$ of OptiPhase MP in a beta counter.

Determination of protein synthesis. Triplicate experiments were performed with various concentrations of IGFs and insulin in culture medium containing alanine $(25 \mathrm{mg} / \mathrm{l})$. After $24 \mathrm{~h}$, the medium was replaced and $0.5 \mu \mathrm{Ci}$ of $\left[{ }^{3} \mathrm{H}\right]$ alanine was added for another $3 \mathrm{~h}$. Further processing was the same as described for determination of DNA synthesis.

Determination of EPO. EPO concentrations were determined by radioimmunoassay exactly as described (2), except that the standards were dissolved in culture medium $(\alpha$-MEM plus $10 \%$ fetal calf serum). EPO production rates by Hep G2 cells are expressed per $10^{6}$ cells.

Ribonuclease protection assay for human EPO $m R N A$. The cRNA probe used in the ribonuclease (RNase) protection assays was obtained by using SP6 RNA polymerase from a 154-base pair fragment from the Pst I site in exon 3 to the Hind II site in exon 4 of the human cDNA. RNase protection assays were performed using conditions described by Ratcliffe et al. (18) with $50 \mu \mathrm{g}$ total RNA in each hybridization.

Binding studies. Competitive binding studies were performed according to Widmer et al. (26). To this end, Hep G2 cells were seeded in multiwell plates at a density of $\sim 5 \times 10^{4}$ cells $/ \mathrm{cm}^{2}$. At
$72 \mathrm{~h}$ after onset of culture, the medium was removed and replaced by PBS containing $7 \mathrm{mM}$ glucose and $1 \%$ bovine serum albumin. Iodinated IGF-I (60 pM) or insulin (40 pM) together with various amounts of unlabeled peptides were added. Cells were incubated at $4^{\circ} \mathrm{C}$ for $4,12,24$, and $48 \mathrm{~h}$. Binding of labeled ligands reached a maximum after $24 \mathrm{~h}$; therefore 24 -h incubations were used as a standard protocol. After the incubation periods, the cells were rinsed with ice-cold PBS, trypsinized with $0.1 \%$ trypsin, and transferred into counting vials. Cellassociated radioactivity was determined in a gamma counter.

Presentation of data. Data are expressed as means $\pm \mathrm{SE}$ of $n$ experiments. Each experiment represents the mean of quadruplicate wells.

Statistics. Student's $t$ test for paired observations was used for the evaluation of statistical differences. $P<0.05$ was considered to be statistically significant.

\section{RESULTS}

Dose-response curves for oxygen on EPO production were performed in the range between 0.5 and $20 \% \mathrm{O}_{2}$ in the incubation atmosphere and for cobalt between 0 and $500 \mu \mathrm{M}$ in the cell culture medium. EPO production rates were found to be maximal at $1 \% \mathrm{O}_{2}$ and $100 \mu \mathrm{M}$ cobalt, and these conditions were therefore chosen as standard stimuli. Cells were seeded at low density of $5 \times 10^{4}$ cells/ $\mathrm{cm}^{2}$, and EPO production rates during $72 \mathrm{~h}$ incubation were $31 \pm 1 \mathrm{mU} / 10^{6}$ cells at $20 \% \mathrm{O}_{2}(n=19$; Fig. 1$)$. FPO formation was $157 \pm 12(n=19)$ and $85 \pm 6 \mathrm{mU} / 10^{6}$ cells $(n=12)$ at $1 \% \mathrm{O}_{2}$ and at $20 \% \mathrm{O}_{2}$ plus $100 \mu \mathrm{M}$ cobalt, respectively (Fig. 1). Cell proliferation was significantly $(P<0.05)$ diminished during $72 \mathrm{~h}$ exposure to low oxygen [cell number $0.98 \pm 0.1 \times 10^{5}$ cells $/ \mathrm{cm}^{2}$ at $1 \% \mathrm{O}_{2}(n=19)$ vs. $1.2 \pm 0.1 \times 10^{5}$ cells $/ \mathrm{cm}^{2}$ at $\left.20 \% \mathrm{O}_{2}(n=19)\right]$ and slightly but not significantly $(P>0.05)$ increased by $100 \mu \mathrm{M}$ cobalt [cell number $1.3 \pm 0.1 \times 10^{5}$ cells $/ \mathrm{cm}^{2}$ $(n=12)]$.

Addition of IGF-I to the culture medium during the 72 $h$ of the experiment led to a concentration-dependent inhibition of EPO production at high and low oxygen tensions and in the presence of cobalt (Fig. 1A). IGF-I did not completely suppress the increase of EPO production in response to low oxygen tension and cobalt but constantly reduced hypoxia- and cobalt-stimulated EPO formation maximally by $50 \%$ (Fig. 1). The half-maximal effect of IGF-I on EPO production was obtained at a IGF-I concentration [half-maximal effect $\left(\mathrm{ED}_{50}\right)$ ] of 5 $\mathrm{nM}$, which was nearly the same at $20 \% \mathrm{O}_{2}, 1 \% \mathrm{O}_{2}$, and $20 \% \mathrm{O}_{2}$ plus $100 \mu \mathrm{M}$ cobalt chloride (Fig. 1 ). IGF-I-induced inhibition of EPO formation was associated with a $>50 \%$ reduction of $\mathrm{EPO}$ mRNA accumulation in response to hypoxia (Fig. 2). IGF-I did not measurably affect EPO mRNA levels at $20 \% \mathrm{O}_{2}$ (Fig. 2).

To test whether the inhibitory action on EPO production was specific for IGF-I, we also examined the effects of IGF-II and insulin, which are structurally related to IGF-I (5, 19). Like IGF-I, IGF-II and insulin caused a concentration-dependent inhibition of EPO formation (Fig. 1, $B$ and $C$ ). $\mathrm{ED}_{50}$ values were obtained with 8 and $80 \mathrm{nM}$ of IGF-II and insulin, respectively (Fig. 1). Similar to IGF-I, saturating concentrations of IGF-II and insulin caused a reduction of EPO formation by somewhat less than $50 \%$ of control (Fig. 1).

In addition to its inhibitory action on EPO production, 

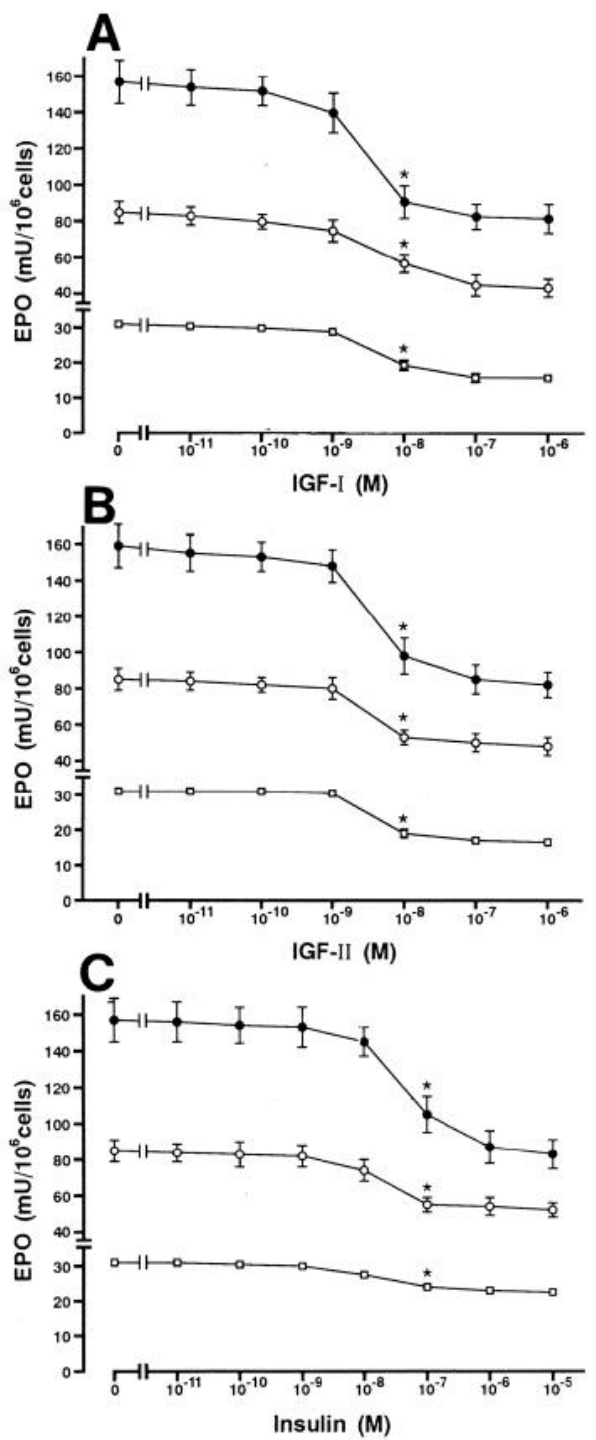

Fig. 1. Dose-response curves for insulin-like growth factor (IGF) I ( $A$ ) and II $(B)$ and insulin $(C)$ on erythropoietin (EPO) production by Hep G2 cells. Cells were incubated for $72 \mathrm{~h}$ at $20 \% \mathrm{O}_{2}$ (ㅁ), $1 \% \mathrm{O}_{2}(\bullet)$, and $20 \%$ $\mathrm{O}_{2}$ plus $100 \mu \mathrm{M} \mathrm{CoCl}_{2}$ (०) with the culture medium ( $\alpha$-minimal essential medium $+10 \%$ fetal calf serum) containing various concentrations of hormones. EPO formation rates are expressed per $10^{6}$ cells. Values are means $\pm \mathrm{SE}$ of $n=8$ experiments, each performed in quadruplicate wells. ${ }^{*}$ Statistically different from control $(P<0.05)$.

IGF-I (100 pM-100 nM) also increased $\left[{ }^{3} \mathrm{H}\right]$ alanine incorporation into protein at 20 and $1 \% \mathrm{O}_{2}$ in a concentration-dependent fashion (Fig. 3). IGF-I-induced stimulation of protein synthesis was paralleled by increased $\left[{ }^{3} \mathrm{H}\right]$ thymidine incorporation into DNA (Fig. 3). Moreover, IGF-I stimulated the incorporation of $\mathrm{D}-\left[{ }^{3} \mathrm{H}\right] \mathrm{glu}-$ cose into glycogen. IGF-I was more effective in stimulating glycogen synthesis under hypoxic than under normoxic conditions (Fig. 3). Similar to IGF-I, IGF-II $(1-100 \mathrm{nM})$ and insulin $(10 \mathrm{nM}-1 \mu \mathrm{M})$ also significantly increased Hep G2 cell proliferation and glycogen synthesis at 20 and $1 \% \mathrm{O}_{2}$ (not shown).

Hep G2 cells express distinct receptors for IGFs and insulin on their cell membranes that cross-react with each other's specific ligand with reduced affinities (17, $25)$. By comparing their relative binding affinities, one

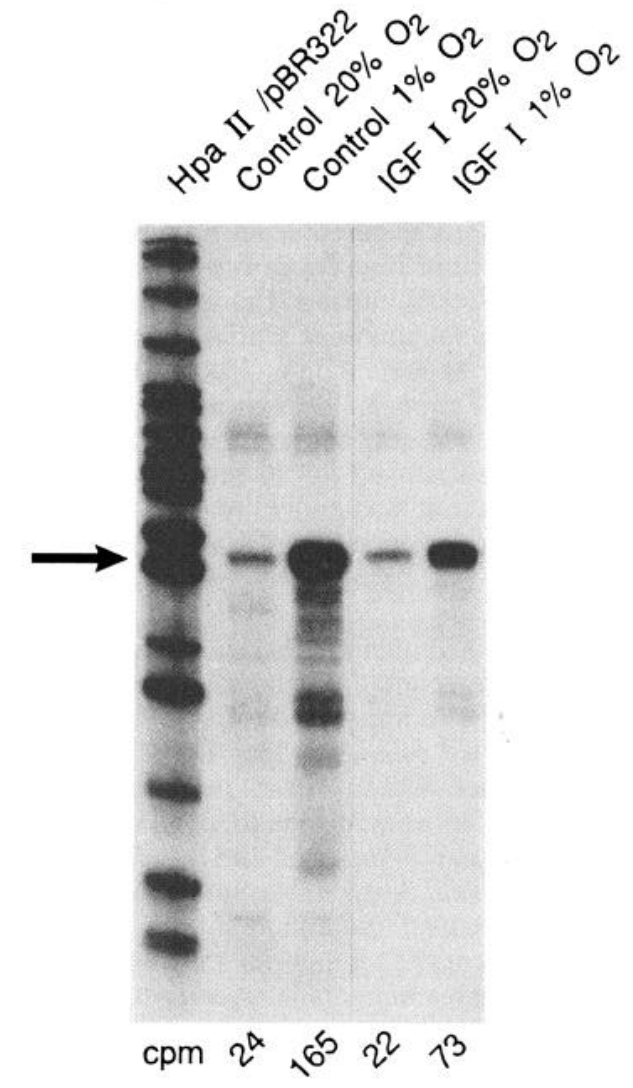

Fig. 2. RNase protection analysis of mRNA from Hep G2 cells. EPO signals are indicated by arrow. Size markers were generated by a $\mathrm{Hpa}$ II digest of pBR322 DNA. Protected bands were excised from gel, set in a solid scintillant, and counted in a beta counter. IGF-I concentration used was $10 \mathrm{nM}$. cpm, counts/min.

may therefore distinguish whether IGF-I and insulin inhibited EPO production by reacting with the same receptor type or with their own specific binding sites. Using intact Hep G2 cells, binding affinities were found to be the same at 20 and $1 \% \mathrm{O}_{2}$. Total binding of ${ }^{125}$ I-IGF-I was $4.8 \%$, and nonspecific binding was $<10 \%$ of total binding (Fig. 4). Nonspecific binding of ${ }^{125}$ I-IGF-I was determined in the presence of saturating concentrations $(10 \mu \mathrm{M})$ of unlabeled ligand. Half-maximal displacement of specific ${ }^{125}$ I-IGF-I binding was obtained with $0.5 \mathrm{nM}$ of unlabeled IGF-I, whereas $\sim 20$-fold-higher concentrations of IGF-II and nearly 600 -fold-higher concentrations of insulin were required (Fig. 4). From Scatchard plot analysis, the affinity constant of the IGF-I receptor for IGF-I was found to be $3 \mathrm{nM}$ at high and low oxygen tensions. Total binding of ${ }^{125} \mathrm{I}$-insulin was $20 \%$, and nonspecific binding was $<10 \%$ of total binding (Fig. 5). The $50 \%$ inhibition of specific ${ }^{125} \mathrm{I}$-insulin binding was achieved with $0.5 \mathrm{nM}$ of unlabeled ligand, whereas $\sim 60$ nM IGF-I was necessary for half-maximal displacement of bound ${ }^{125} \mathrm{I}$-insulin (Fig. 5). Insulin (100 pM-10 $\left.\mu \mathrm{M}\right)$ did not inhibit specific ${ }^{125}$ I-IGF-II binding (not shown).

\section{DISCUSSION}

IGF-I, the peripheral mediator of growth hormone effects $(5,28)$, has recently been found to stimulate EPO 

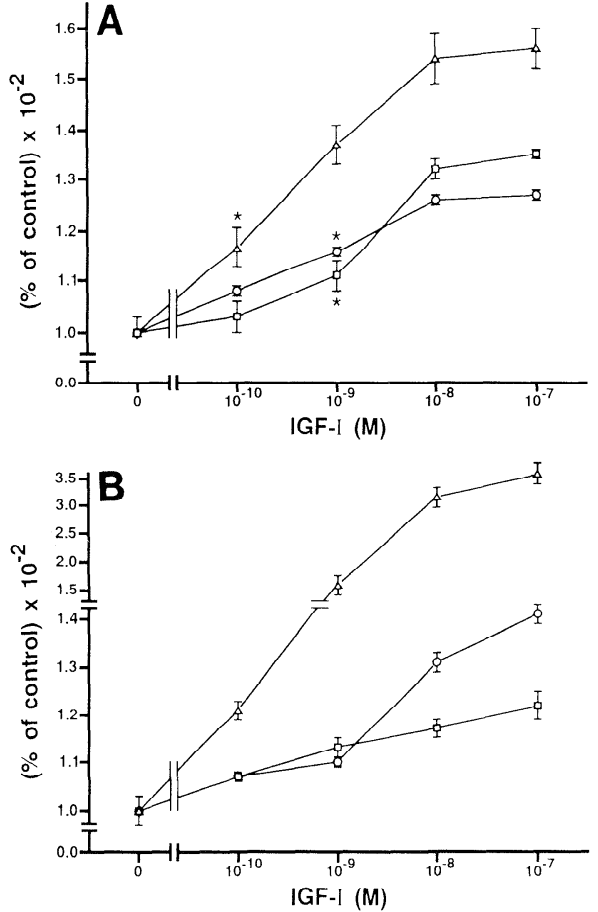

Fig. 3. Concentration-dependent stimulation of protein and DNA synthesis and of $\left[{ }^{3} \mathrm{H}\right]$ glucose incorporation into glycogen $(\triangle)$ by IGF-I. $\left[{ }^{3} \mathrm{H}\right]$ alanine $(\mathrm{O})$ and $\left[{ }^{3} \mathrm{H}\right]$ thymidine $(\square)$ incorporation into TCA precip itable material were taken as a measure for protein and DNA synthesis, respectively. Experiments were performed at $20(A)$ and $1 \% \mathrm{O}_{2}(B)$ Values are means \pm SE of 5 different experiments, each performed in quadruplicate wells. ${ }^{*}$ Significantly different from control $(P<0.05)$.

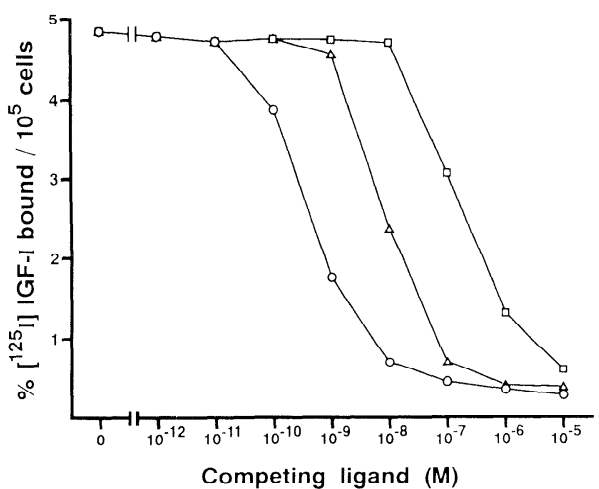

Fig. 4. Competitive inhibition of binding of ${ }^{125}$ I-IGF-I to Hep $\mathrm{G} 2$ cells by unlabeled IGF-I (O), IGF-II $(\triangle)$, and insulin ( $\square$ ). Cells were incubated under normoxic conditions $\left(20 \% \mathrm{O}_{2}\right)$ at $4^{\circ} \mathrm{C}$ for $24 \mathrm{~h}$ in phosphatebuffered saline (PBS) containing $7 \mathrm{mM}$ glucose and $1 \%$ bovine serum albumin together with $60 \mathrm{pM}$ iodinated IGF-I and various amounts of unlabeled hormones. Total binding per $10^{5}$ cells is plotted as percentage of added radioactivity against concentration of unlabeled ligands. No significant differences were found between ${ }^{125}$ I-IGF binding at 20 and $1 \% \mathrm{O}_{2}$ (not shown). Values are means of 3 representative experiments, each performed in quadruplicate wells.

formation in hypophysectomized rats (11). The mechanism, however, by which IGF-I increased EPO production in hypophysectomized animals is unknown. In particular it is unclear whether IGF-I exerted a direct effect on EPO-producing cells in the kidneys or in the liver. In the present study we have therefore examined whether IGF-I directly modulates EPO formation at the cellular level.

To our knowledge, highly enriched preparations of EPO-producing cells from neither the kidneys nor the

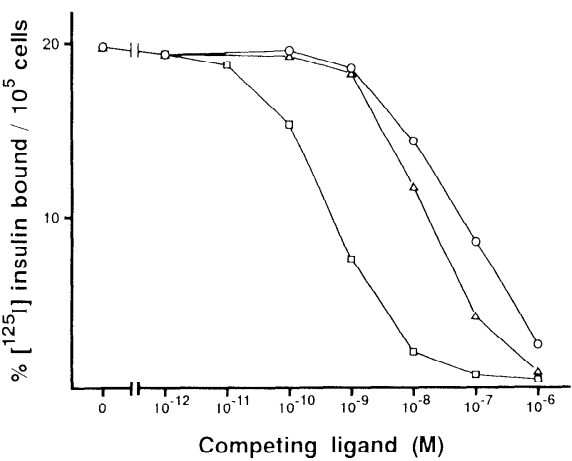

Fig. 5. Displacement of ${ }^{125}{ }^{2}$-insulin binding by unlabeled insulin ( $\square$ ), IGF-I $(0)$, and IGF-II $(\triangle)$. Hep G2 cells were incubated in an atmosphere of $20 \% \quad \mathrm{O}_{2}$ at $4^{\circ} \mathrm{C}$ for $24 \mathrm{~h}$. Iodinated insulin $(40 \mathrm{pM})$ and various amounts of unlabeled hormones were added to the incubation solution (PBS containing $7 \mathrm{mM}$ glucose and $1 \%$ bovine serum albumin). Cellassociated radioactivity was determined in a gamma counter. No significant differences of ${ }^{125}$ I-insulin binding were found between incubation at 20 and $1 \% \mathrm{O}_{2}$ (not shown). Values are means of 3 representative experiments, each performed in quadruplicate wells.

liver are yet available as primary cultures. In view of those circumstances, we have used the human hepatoma cells Hep G2 (8), which not only (like the intact organism) produce EPO in an oxygen- and cobalt-regulated fashion $(4,15,24)$ but also express distinct cell surface receptors for IGFs and insulin $(17,25)$.

We found that IGF-I ( $30 \mathrm{pM}-3 \mathrm{nM})$ inhibited EPO formation at 20 and $1 \% \quad \mathrm{O}_{2}$ and in the presence of cobalt chloride with an $\mathrm{ED}_{50}$ value of $5 \mathrm{nM}$ (Fig. $1 A$ ). IGF-Iinduced inhibition of EPO formation was, at least in part, due to decreased FPO gene transcription, because EPO mRNA accumulation in response to hypoxia was significantly reduced by IGF-I (Fig. 2). IGF-II inhibited EPO formation nearly with the same potency as IGF-I did $\left(\mathrm{ED}_{50} 8 \mathrm{nM}\right)$, whereas the insulin concentration required to decrease EPO production half maximally was $80 \mathrm{nM}$ (Fig. 1, $B$ and $C$ ).

If we assume that IGFs and insulin specifically decreased EPO formation in Hep G2 cells, then one should expect that their effects were due to a direct interaction with specific cell membrane receptors. Hep G2 cells express distinct receptors for IGF-I and insulin on their cell surface $(17,25)$, and part of those binding sites has recently been found to be hybrids composed of an IGF-I and an insulin receptor $\alpha$ - $\beta$-heterodimer (14). First evidence for which of those receptor types were mediating the inhibitory effects of IGFs and insulin on EPO production can be obtained by comparing their relative binding affinities. To this end we performed competitive binding studies, and we found that the apparent $K_{\mathrm{d}}$ $(3 \mathrm{nM})$ for IGF-I binding to its own specific receptor was nearly the same as the $\mathrm{ED}_{50}$ value $(5 \mathrm{nM})$ for IGF-Iinduced inhibition of EPO formation. In conclusion, IGF-I exerted its effects most likely through an interaction with the IGF-I receptor. For comparison, the $K_{\mathrm{d}}$ $(\approx 0.3 \mathrm{nM})$ for the binding of insulin to its specific receptor was $>25$-fold lower than the insulin concentration required to reduce EPO secretion half maximally (80 $\mathrm{nM})$. Therefore it appears rather unlikely that insulin decreased EPO production by populating its own specific binding site. However, comparing the dose-response 
curves for insulin with the relatively low affinity of insulin for the IGF-I receptor (apparent $K_{\mathrm{d}} \approx 360 \mathrm{nM}$ ), our findings strongly suggest that insulin reduced EPO formation by cross-reacting with the IGF-I receptor.

For the following lines of evidence we think that the inhibitory effect of IGF-I on EPO production was due to a specific rather than an unspecific (toxic) action on Hep G2 cells. First, IGF-I stimulated protein synthesis in Hep G2 cells in a concentration-dependent fashion at high and low oxygen tensions (Fig. 3). In conclusion, decreased EPO gene expression did not result from an overall inhibition of protein synthesis caused by IGF-I. Second, IGF-I still exerted some other characteristic effects such as a dose-dependent increase of DNA synthesis and glycogen formation (Fig. 3).

The question arises about the cellular mechanism by which IGF-I reduced EPO production in Hep G2 cells. It is fairly established that the IGF-I receptor acts as a tyrosine kinase (13), and it is reasonable, therefore, to assume that such a phosphorylation step is also involved in the action of IGF-I on EPO formation by Hep G2 cells. An interesting action of IGF's action in this context was that it only partially inhibited EPO production (Fig. 1). Such a partial decrease of stimulated EPO production by Hep G2 cells has recently also been found for cytokines such as tumor necrosis factor- $\alpha$ and interleukin-1 (7). Like IGF-I, tumor necrosis factor- $\alpha$ and interleukin- 1 are also thought to act via specific kinases $(12,20)$. It is not unlikely, therefore, that IGF-I and cytokines have the same target for phosphorylation in the cascade controlling oxygen-regulated EPO production. It remains to be clarified whether specific cellular effects of IGF-I such as stimulation of glycogen synthesis (Fig. 3) or increased amino acid uptake (25) were indirectly involved in its inhibitory action on EPO gene expression.

In summary, we found that IGFs and insulin decreased oxygen- and cobalt-regulated EPO formation in Hep G2 cells, and those effects were at least in part due to decreased EPO gene transcription. Moreover, our findings also suggest that both IGFs and insulin inhibited EPO production through a specific interaction with the IGF-I receptor.

In asking for the potential physiological relevance of those findings obtained with hepatoma cells, the answer is based upon the assumption that the signal transduction mechanisms for oxygen-regulated EPO formation are similar in Hep G2 cells and in normal hepatocytes. Because primary cultures of hepatocytes that produce EPO in a regulated fashion have not yet been established, there is at present no possibility to prove or disprove this assumption. Within the limits of the experimental model that was used in this study, one should expect that hepatic EPO production is inhibited when the liver increases its IGF-I formation, a situation that occurs during the first weeks after birth (10). Because EPO production is known to shift from the liver to the kidneys during this time period (27), we can speculate that IGF-I could play a role in this organ shift, which is yet unexplained.

We thank U. Bolliger and U. Vogel for expert technical assistance and C. Gasser for doing the artwork.
This study was supported by Swiss National Science Foundation Grant 31-9433.88.

Address for reprint requests: H. Scholz, Physiologisches Institut der Universität Regensburg, Universitätsstrasse 31, W-8400 Regensburg, FRG.

Received 2 January 1992; accepted in final form 1 April 1992.

\section{REFERENCES}

1. Claustres, M., P. Chatelain, and C. Sultan. Insulin-like growth factor I stimulates human erythroid colony formation in vitro. J. Clin. Endocrinol. Metab. 65: 78-82, 1987.

2. Eckardt, K. U., A. Kurtz, P. Hirth, P. Scigalla, L. Wieczorek, and C. Bauer. Evaluation of the stability of human erythropoietin in samples for radioimmunoassay. Klin. Wochenschr. 66: 241-245, 1988.

3. Fried, W. The liver as a source of extrarenal erythropoietin. Blood 40: 671-677, 1970.

4. Goldberg, M. A., G. A. Glass, J. M. Cunningham, and H. F. Bunn. The regulated expression of erythropoietin by two human hepatoma cell lines. Proc. Natl. Acad. Sci. USA 84: 7972-7976, 1987.

5. Humbel, R. E. Insulin-like growth factors I and II. Eur. J. Biochem. 190: 445-462, 1990.

6. Jelkmann, W. Renal erythropoietin: properties and production. Rev. Physiol. Biochem. Pharmacol. 104: 140-215, 1986.

7. Jelkmann, W., M. Wolff, and J. Fandrey. Modulation of the production of erythropoietin by cytokines: in vitro studies and their clinical implications. Contrib. Nephrol. 87: 68-77, 1990.

8. Knowles, B. B., C. C. Howe, and D. P. Aden. Human hepatocellular carcinous cell line secretes the major plasma proteins with hepatitis B surface antigen. Science Wash. DC 209: 497-498, 1980.

9. Kurtz, A., W. Jelkmann, and C. Bauer. A new candidate for the regulation of erythropoiesis. Insulin-like growth factor I. FEBS Lett. 149: 105-108, 1982.

10. Kurtz, A., R. Matter, K. U. Eckardt, and J. Zapf. Erythropoiesis, serum erythropoietin, and serum IGF-I in rats during accelerated growth. Acta Endocrinol. 122: 323-328, 1990.

11. Kurtz, A., J. Zapf, K. U. Eckardt, G. Clemons, E. R. Froesch, and C. Bauer. Insulin-like growth factor I stimulates erythropoiesis in hypophysectomized rats. Proc. Natl. Acad. Sci. USA 85: 7825-7829, 1988.

12. Martin, M., D. H. Lovett, M. Szamel, and K. Resch. Characterization of the interleukin-1-induced tyrosine phosphorylation of a $41-\mathrm{kDa}$ plasma membrane protein of the human tumor cell line K 562. Eur. J. Biochem. 180: 343-350, 1989.

13. Morgan, D. O., K. Jarnagin, and R. A. Roth. Purification and characterization of the receptor for insulin-like growth factor I. Biochemistry 25: 5560-5564, 1986.

14. Moxham, C. P., V. Duronio, and S. Jacobs. Insulin-like growth factor I receptor $\beta$-subunit heterogeneity: evidence for hybrid tetramers composed of insulin-like growth factor I and insulin receptor heterodimers. J. Biol. Chem. 264: 13228-13244, 1989.

15. Nielsen, O., S. J. Schuster, R. Kaufman, A. E. Erslev, and J. Caro. Regulation of erythropoietin production in a human hepatoblastoma cell line. Blood 70: 1904-1909, 1987.

16. Philipps, A. F., B. Persson, K. Hall, M. Lake, A. Skottner, T. Sanengen, and V. Sara. The effects of biosynthetic insulinlike growth factor-I supplementation on somatic growth, maturation and erythropoiesis of the neonatal rat. Pediatr. Res. 23: 298305, 1988.

17. Podskalny, J. M., S. R. E. Silverman, D. Tran, J. L. Carpentier, L. Orci, and P. Gorden. Insulin receptors and bioresponses in a human liver cell line (Hep G2). Eur. J. Biochem. 150: 401-407, 1985.

18. Ratcliffe, P. J., R. W. Jones, E. Phillips, L. G. Nicholls, and J. I. Bell. Oxygen-dependent modulation of erythropoietin mRNA levels in isolated rat kidneys studied by RNase protection. J. Exp. Med. 172: 657-660, 1990.

19. Rinderknecht, E., and R. E. Humbel. The amino acid sequence of human insulin-like growth factor I and its structural homology with proinsulin. J. Biol. Chem. 253: 2769-2776, 1978.

20. Robaye, B., A. Hepburn, R. Lecocq, W. Fiers, J-M. Boeynaems, and J. E. Dumont. Tumor necrosis factor-alpha induces 
the phosphorylation of $28 \mathrm{kDa}$ stress proteins in endothelial cells: possible role in protection against cytotoxicity? Biochem. Biophys. Res. Commun. 163: 301-308, 1989.

21. Sawada, K., S. B. Krantz, E. N. Dessypris, S. T. Koury, and S. T. Sawyer. Human colony-forming units-erythroid do not require accessory cells, but do require direct interaction with insulin-like growth factor I and/or insulin for erythroid development. J. Clin. Invest. 83: 1701-1709, 1989.

22. Schmid, C., T. Steiner, and E. R. Froesch. Insulin-like growth factors stimulate synthesis of nucleic acids and glycogen in cultured calvaria cells. Calcif. Tissue Int. 35: 578-585, 1983.

23. Schuster, S. J., J. H. Wilson, A. J. Erslev, and J. Caro. Physiologic regulation and tissue localization of renal EPO mRNA. Blood 70: 316-318, 1987.

24. Ueno, M., I. Seferynska, B. Beckman, J. Brookins, J. Nakashima, and J. W. Fisher. Enhanced erythropoietin secretion in hepatoblastoma cells in response to hypoxia. Am. J. Physiol. 257 (Cell Physiol. 26): C743-C749, 1989.

25. Verspohl, E. J., B. A. Maddux, and I. D. Goldfine. Insulin and insulin-like growth factor I regulate the same biological func- tions in Hep G2 cells via their own specific receptors. J. Clin. Endocrinol. Metab. 67: 169-174, 1988.

26. Widmer, U., C. Schmid, J. Zapf, and E. R. Froesch. Effects of insulin-like growth factors on chick embryo hepatocytes. Acta Endocrinol. 108: 237-244, 1985.

27. Zanjani, E. D., J. L. Ascensao, P. B. McGlave, M. Banisadre, and R. C. Ash. Studies on the liver to kidney switch of erythropoietin production. J. Clin. Invest. 76: 1183-1188, 1981.

28. Zapf, J., C. Schmid, and E. R. Froesch. Biological and immunological properties of insulin-like growth factors (IGF) I and II. Clin. Endocrinol. Metab. 13: 3-30, 1984.

29. Zapf, J., C. Schoenle, and E. R. Froesch. Insulin-like growth factors I and II: some biological actions and receptor binding characteristics of two purified constituents of nonsuppressible insulin-like activity of human serum. Eur. J. Biochem. 87: 285 296, 1978.

30. Zapf, J., M. Waldvogel, F. Schoenle, and E. R. Froesch. Effect of insulin on glucose transport and metabolism in adipose tissue and sceletal muscle of hypophysectomized rats. FE'BS Lett. 135: 199-202, 1981.

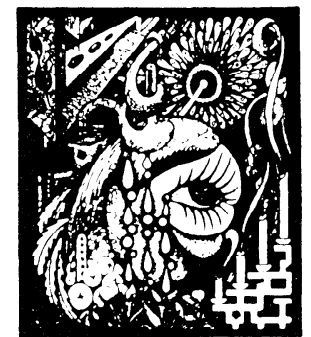

